\title{
Lipid nanoparticle technologies for the study of G protein-coupled receptors in lipid environments
}

\author{
Steven Lavington ${ }^{1} \cdot$ Anthony Watts ${ }^{1}$ [D \\ Received: 2 November 2020 / Accepted: 6 November 2020 / Published online: 19 November 2020 \\ (C) The Author(s) 2020
}

\begin{abstract}
G protein-coupled receptors (GPCRs) are a large family of integral membrane proteins which conduct a wide range of biological roles and represent significant drug targets. Most biophysical and structural studies of GPCRs have been conducted on detergentsolubilised receptors, and it is clear that detergents can have detrimental effects on GPCR function. Simultaneously, there is increasing appreciation of roles for specific lipids in modulation of GPCR function. Lipid nanoparticles such as nanodiscs and styrene maleic acid lipid particles (SMALPs) offer opportunities to study integral membrane proteins in lipid environments, in a form that is soluble and amenable to structural and biophysical experiments. Here, we review the application of lipid nanoparticle technologies to the study of GPCRs, assessing the relative merits and limitations of each system. We highlight how these technologies can provide superior platforms to detergents for structural and biophysical studies of GPCRs and inform on roles for protein-lipid interactions in GPCR function.
\end{abstract}

Keywords Nanodisc $\cdot \mathrm{rHDL} \cdot$ Lipodisq $\cdot \mathrm{SMALP} \cdot$ Lipid-protein interactions $\cdot \mathrm{G}$ protein-coupled receptor

\section{Introduction}

G protein-coupled receptors (GPCRs) constitute a family of over 800 integral membrane proteins, unified by a shared seven transmembrane helix architecture (Pierce et al. 2002; Fredriksson et al. 2003). Together, GPCRs respond to a diverse array of ligands, including ions, fatty acids, nucleotides and peptides, and their signalling is a component of a great many biological processes. Similarly, GPCR dysfunction is associated with a range of pathologies, including diabetes and obesity (Riddy et al. 2018), cancers (Dorsam and Gutkind 2007) and neurodegenerative diseases (Huang et al. 2017). GPCRs are also valuable drug targets, with a large portion of FDAapproved drugs targeting a relatively small number of receptors (Hauser et al. 2017). There is therefore considerable value in understanding the mechanism of action of these receptors.

Canonically, GPCR signalling involves the binding of ligands to the extracellular portion of a receptor, which in turn promotes signalling through heterotrimeric $G$ proteins, of

Anthony Watts

anthony.watts@bioch.ox.ac.uk

1 Biochemistry Department, University of Oxford, South Parks Road, Oxford OX1 3QU, UK which there are four subtypes (Strathmann and Gautam 1991; Downes and Gautam 1999). Interactions of GPCRs with arrestins can modulate these signals and produce $G$ protein-independent signals (Reiter and Lefkowitz 2006). Given that a single receptor may signal to multiple $\mathrm{G}$ protein subtypes, a great diversity of signalling responses is possible for a single receptor.

There has been tremendous effort in trying to understand the molecular basis of GPCR signalling (reviewed in (Manglik and Kruse 2017; Weis and Kobilka 2018)). Biophysical techniques such as nuclear magnetic resonance and electron paramagnetic resonance spectroscopies have described complex receptor conformational landscapes and how receptor activation relates to these landscapes (Liu et al. 2012; Nygaard et al. 2013; Manglik et al. 2015; Sounier et al. 2015; Ye et al. 2016; Gregorio et al. 2017; Latorraca et al. 2017; Wingler et al. 2019). X-ray crystallography and single-particle cryo-EM have provided a wealth of structural information on a large number of individual GPCRs, with structures available for a range of receptor conformational states and receptorsignalling partner complexes now available (reviewed in (Manglik and Kruse 2017; Weis and Kobilka 2018; GarcíaNafría and Tate 2019; Wang et al. 2020)).

A majority of studies addressing molecular mechanisms of GPCR signalling make use of receptors solubilised and 
purified in detergents. GPCRs have evolved to function in the lipid bilayers of biological membranes, and solubilisation of receptors by detergents necessarily disrupts this environment. Detergent solubilisation is often accompanied by a reduction in receptor thermostability (Serrano-Vega et al. 2008; Grisshammer 2009; Lee et al. 2016a) which can lead to loss of receptor activity through denaturation and aggregation. For some GPCRs, this is so severe that they are intractable to study in detergent, and in response to this, technologies to thermostabilise GPCRs through sequence modification have been developed (Tate and Schertler 2009; Dodevski and Plückthun 2011). In addition, detergents may have deleterious effects on the activities of GPCR signalling partners and their interaction with GPCRs; for example, the activity of heterotrimeric $\mathrm{G}$ proteins may be significantly perturbed by detergents (Sarvazyan et al. 1998; Kubota et al. 2009). Detergents such as $n$-dodecyl $\beta$-D-maltoside (DDM) and lauryl maltose neopentyl glycol (LMNG) have become popular for solubilising GPCRs (Munk et al. 2019), and there has been progress in developing detergents with even greater preservation of receptor activity (Bae et al. 2016, 2019; Das et al. 2019).

Even if a receptor is sufficiently stable in detergent, the micelle structures adopted by detergents are poor mimics of a lipid bilayer environment. The bilayer environment may modulate GPCR activity through specific lipid contacts and/ or through changes in certain physical properties of the bilayer such as lipid dynamics and order, lateral pressure and thickness (reviewed in (Oates and Watts 2011)). Indeed, GPCRs have been shown to interact selectively with specific phospholipids (Watts et al. 1979; Soubias et al. 2006, 2010; Yen et al. 2018), and specific phospholipids can modulate receptor functions such as ligand binding (Oates et al. 2012; Rues et al. 2016; Dawaliby et al. 2016), receptor activation (Dawaliby et al. 2016), G protein binding and coupling (Bubis 1998; Jastrzebska et al. 2009; Inagaki et al. 2012; Dijkman and Watts 2015; Yen et al. 2018; Strohman et al. 2019) and recruitment of GPCR kinases (GRKs) (Komolov et al. 2017) and arrestins (Sommer et al. 2006; Lee et al. 2020; Staus et al. 2020). In addition, GPCR signalling partners may have lipid-binding properties, as has been reported for $\mathrm{G}$ proteins (Vögler et al. 2004; Crouthamel et al. 2008; Kosloff et al. 2008; Álvarez et al. 2015), arrestins (Gaidarov et al. 1999; Bayburt et al. 2011; Lally et al. 2017) and GRKs (Onorato et al. 1995; DebBurman et al. 1996; Pitcher et al. 1996).

It is therefore apparent that the absence of a bilayer structure and/or specific lipids and the presence of detergents can have deleterious effects on the behaviour of a GPCR and its signalling partners. In response, membrane mimetic systems have been developed and adapted to study GPCRs in lipidic environments. In particular, lipid nanoparticle systems such as nanodiscs and styrene maleic acid lipid particles (SMALPs) are increasingly used as platforms for biophysical and structural studies of GPCRs. These technologies feature nanoscale ( $\sim 10 \mathrm{~nm}$ in diameter) lipid bilayers stabilised by amphipathic protein sequences or synthetic amphipathic polymers (Fig. 1). Their discoidal morphology allows both ligands and intracellular signalling partners such as $G$ proteins access to their binding sites, whilst their small size allows the GPCR lipid nanoparticle to be treated in much the same way as a protein in a detergent micelle.

Here, we will review the application of lipid nanoparticle technologies to the study of GPCRs in lipid environments, addressing their advantages and limitations and highlighting their contribution to our understanding of GPCR signalling and its modulation by lipids.

\section{Nanodiscs}

Nanodiscs are lipid protein nanoparticles consisting of a discoidal lipid bilayer sealed by a 'belt' formed by a dimer of membrane scaffold proteins (MSPs) (Bayburt et al. 2002; Denisov and Grinkova 2004). MSPs are amphipathic alphahelical proteins developed by the Sligar laboratory, derived from the ApoA-1 apolipoprotein of high-density lipoproteins. MSPs with different numbers of helical repeats are available, producing nanoparticles of different diameters (Denisov and Grinkova 2004; Ritchie et al. 2009). In addition to MSPs, nanoscale lipid-protein particles can be formed using wildtype ApoA-1, which can be purified in high levels from serum, but may produce particles less homogeneous in size (Vélez-Ruiz and Sunahara 2011; Denisov and Sligar 2017). The term 'reconstituted high density lipoprotein' (rHDL) is sometimes used to refer to lipid nanoparticles formed with ApoA-1 or MSPs. In addition, technologies have been developed using ApoA-1 variants which allow production of circularised nanodiscs (cNDs) with improved stability and decreased dispersity in size (Nasr et al. 2016; Nasr and Wagner 2018). Typically, nanodiscs are formed by incubation of a purified membrane protein with lipids, before addition of MSP and removal of detergent by adsorbent polystyrene beads. The resulting sample can then be purified by sizeexclusion chromatography, and empty discs removed by affinity chromatography where necessary (Goddard et al. 2015). Nanodiscs with $\sim 9-17 \mathrm{~nm}$ diameters can be formed using MSPs (Ritchie et al. 2009), whilst wild-type ApoA-1 can produce nanoparticles of 9-12 nm diameter (Vélez-Ruiz and Sunahara 2011; Dawaliby et al. 2016) and cNDs of up to $80 \mathrm{~nm}$ are possible (Nasr and Wagner 2018). The nanodisc system appears to be tolerant of a variety of lipid types (Ritchie et al. 2009) (see also Table 1), such that considerable control over the final lipid composition of the nanodisc bilayer can be exercised.

Nanodiscs therefore offer the opportunity to reconstitute a GPCR into a lipid environment of defined lipid composition 

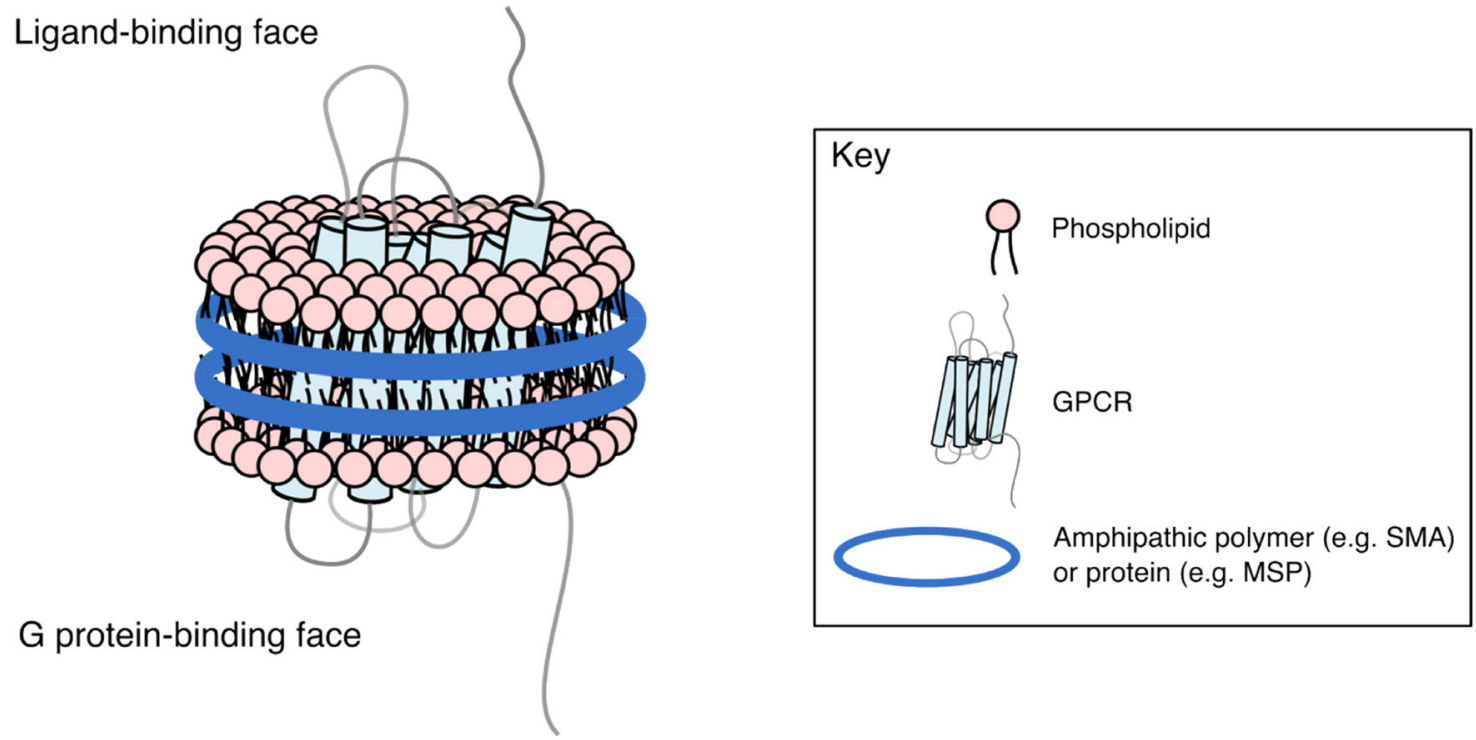

Fig. 1 A GPCR lipid nanoparticle. Lipid nanoparticles consist of phospholipids in a discoidal bilayer, solubilised by an amphipathic polymer or protein. Both the ligand-binding face and G protein binding faces of the reconstituted GPCR are accessible to bulk solvent

and size, in which both faces of the GPCR are solvent accessible. The first two demonstrations of nanodisc/rHDL reconstitution of a GPCR employed the $\beta_{2}$-adrenergic receptor ( $\left.\beta_{2} A R\right)$ (Leitz et al. 2006; Whorton et al. 2007). In a 2006 paper, Sligar and colleagues used MSP1 and the phosphatidylcholine (PC) lipid 1-palmitoyl-2-oleoyl-sn-glycero-3phosphocholine (POPC) (Fig. 2) to reconstitute the receptor, whilst a 2007 paper used the wild-type ApoA-1 protein and a mix of POPC and the phosphatidylglycerol (PG) lipid 1palmitoyl-2-oleoyl-sn-glycero-3-phospho-(1'-rac-glycerol) (POPG). In both cases, the monomeric, reconstituted receptor was functional with respect to ligand binding and nucleotide exchange at the $\mathrm{G}_{\mathrm{s}}$ heterotrimer. Since these initial studies, a wide selection of GPCRs have been reconstituted into nanodiscs and studied by a range of biochemical and biophysical methods (Table 1). Together, the literature demonstrates that it is possible for a GPCR in nanodiscs to bind to ligands, bind and couple to G proteins, recruit GPCR kinases (GRKs) and recruit arrestins (Table 1).

It is generally assumed that the lipid bilayer environment of a nanodisc provides a more native-like environment for the study of GPCRs when compared to detergent micelles, and several reports have directly compared GPCR activity in micelles and nanodiscs. For rhodopsin, the nanodiscreconstituted receptor activates the transducin $G$ protein heterotrimer to a similar degree to the receptor in native membranes and to a much higher degree than in detergent (Whorton et al. 2007). Moreover, rhodopsin proceeds through similar photointermediates with similar kinetics in both nanodiscs and native membranes, whereas detergent solution perturbs the kinetics of late photointermediates considerably (Tsukamoto et al. 2011). A DEER study of rhodopsin in nanodiscs and detergent reveals that the receptor adopts a more complex conformational ensemble in nanodiscs than in detergent (Van Eps et al. 2017), presumably reflecting a more native-like situation that allows the receptor to couple to multiple signalling partners. For the $\beta_{2}$-adrenergic receptor $\left(\beta_{2} \mathrm{AR}\right)$, an NMR study of the deuterated receptor demonstrated greater constitutive activity and slower conformational exchange between receptor active and inactive states in a nanodisc compared to detergents (Kofuku et al. 2014). A recent ${ }^{19}$ F-NMR study similarly found increased constitutive activity for $\beta_{2} \mathrm{AR}$ in POPC/POPG nanodiscs compared to detergent and that the receptor in nanodiscs stimulated considerably more GTP turnover at the $\mathrm{G}_{\mathrm{s}}$ heterotrimer than in detergent (Staus et al. 2019). It is therefore clear that nanodiscs can provide a superior environment for the in vitro study of GPCR signalling when compared to detergents.

Nanodiscs may support higher GPCR activity than detergents because of the absence of inhibitory effects of detergents, the presence of a bilayer structure and/or the presence of specific lipids. Studies on GPCRs in nanodiscs in which lipid composition is varied suggest that specific lipids can have significant modulatory effects on GPCRs in nanodiscs, and so the degree to which native-like receptor activity is supported will depend on nanodisc lipid composition. In a 2016 study, the $\beta_{2} \mathrm{AR}$ in ApoA-1 rHDLs containing one of five different lipids was used; acidic PG, phosphatidylserine (PS) and phosphatidylinositol (PI) lipids, and zwitterionic phosphatidylethanolamine (PE) and PC lipids, all with dioleoyl (DO) acyl chains (Dawaliby et al. 2016) (Fig. 2). All five compositions support ligand binding and receptor activation by a nanobody, but acidic phospholipids, especially PG, promote highest ligand binding affinity and augment receptor activation. PE, by contrast, favours an inactive receptor state. In a subsequent study, it was found that nanodiscs 


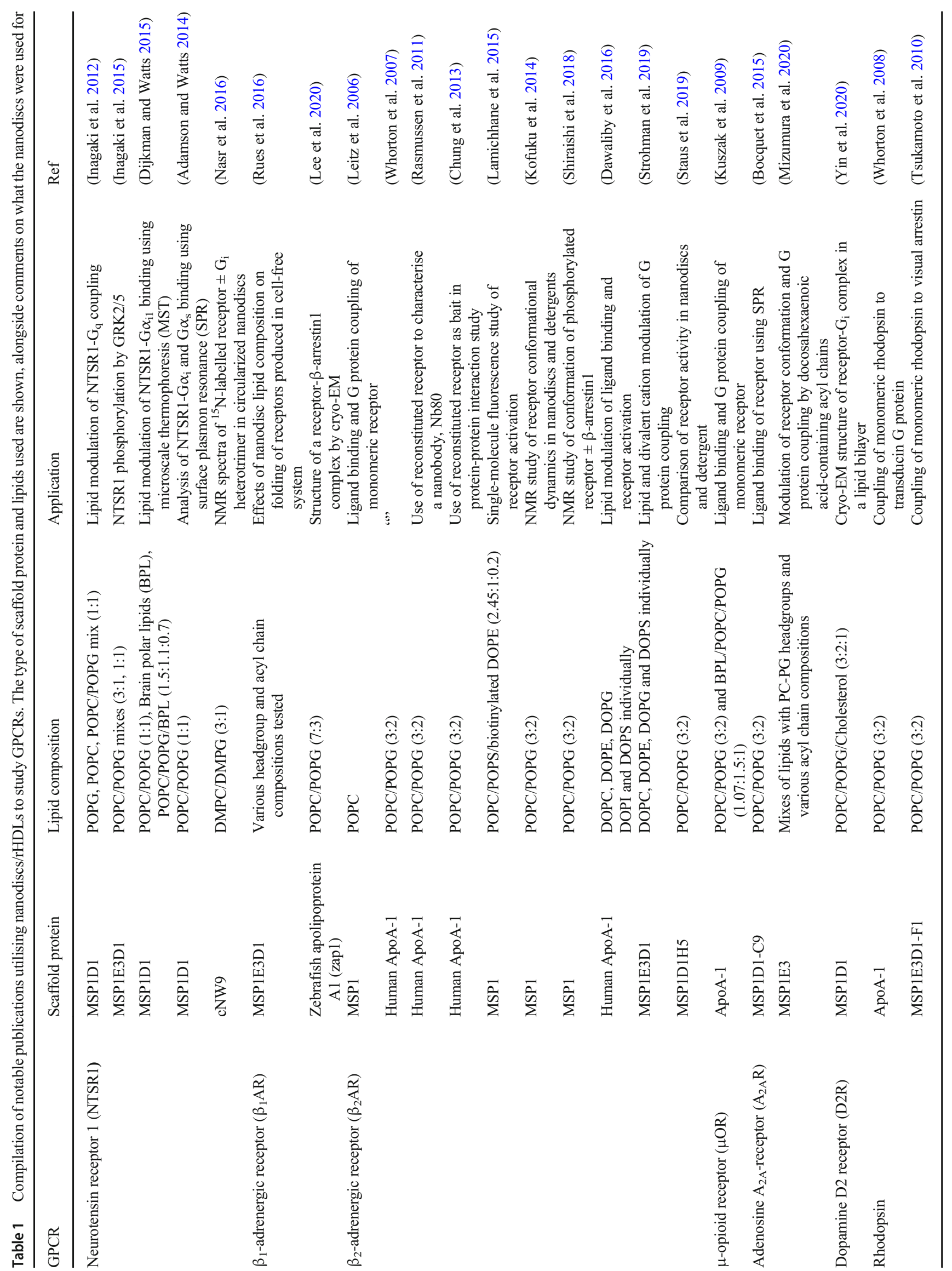




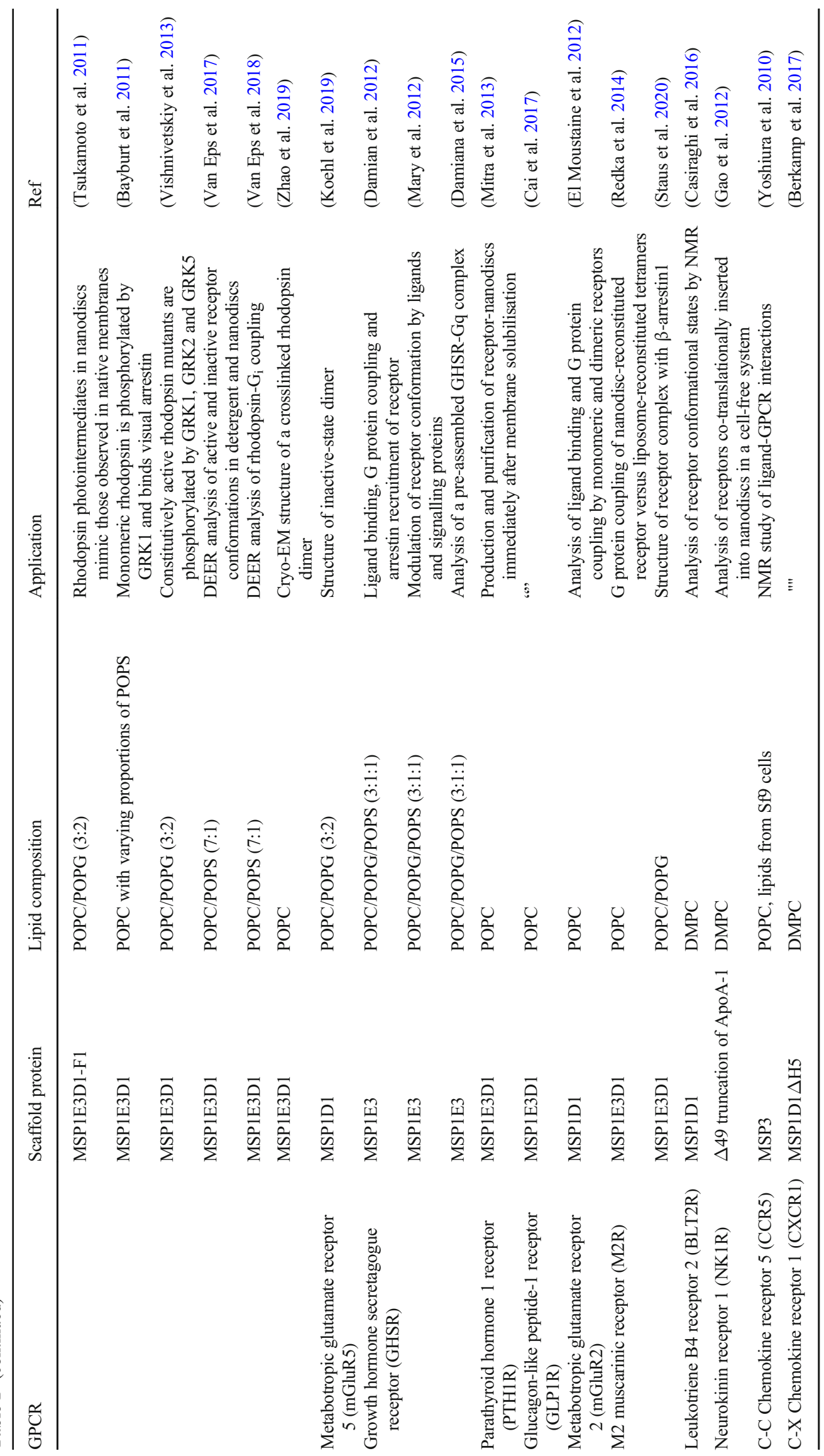


Fig. 2 Structures of lipid headgroups and acyl chains. Chemical structures are shown for lipid headgroup and acyl chain structures that have been used to reconstitute GPCRs in nanodiscs

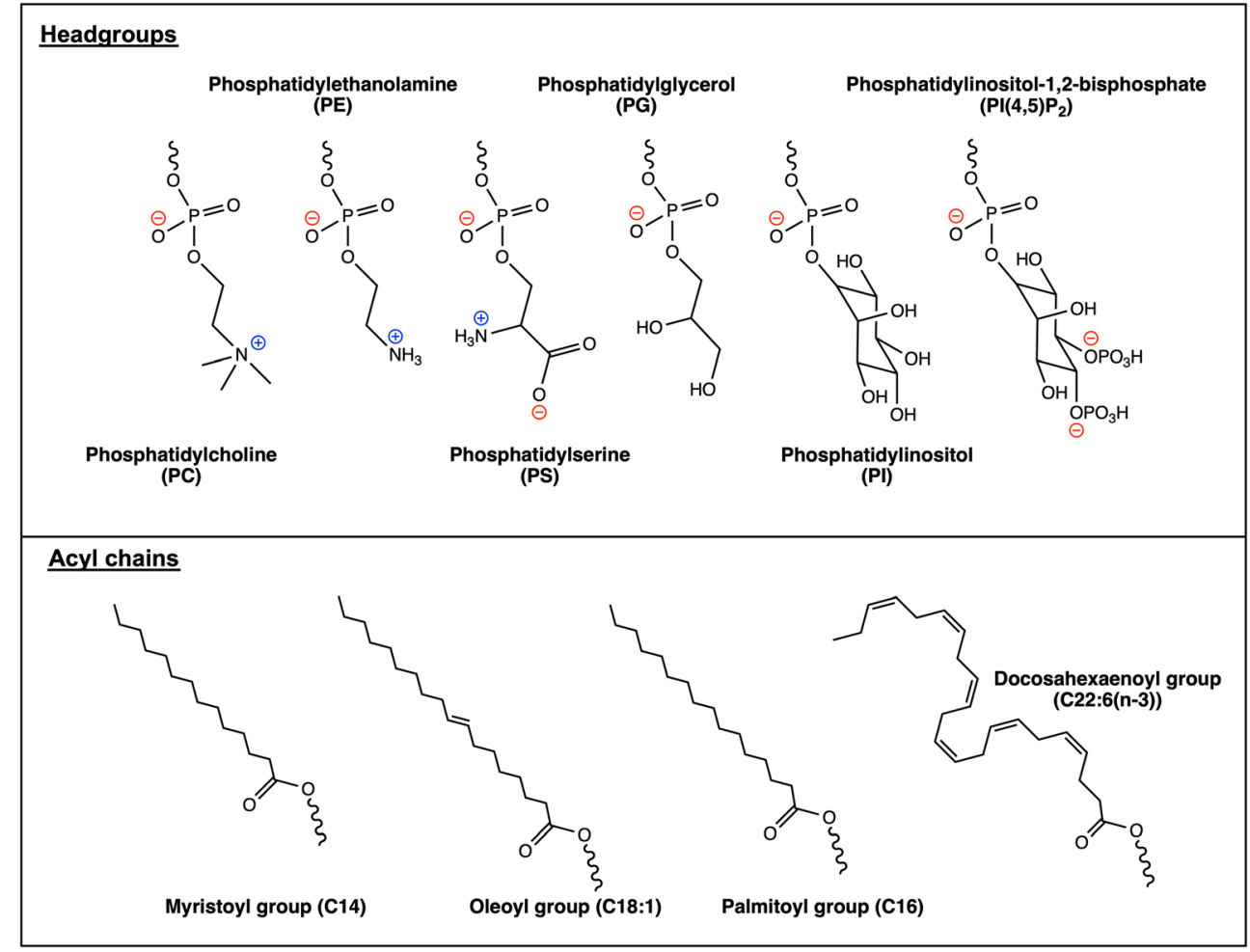

containing PG and PS headgroups modulate $\beta_{2} \mathrm{AR}$ activation by the $G_{s}$ heterotrimer but surprisingly are inhibitory to $\beta_{2} A R$ activation by the $G_{i 3}$ heterotrimer in the absence of divalent cations (Strohman et al. 2019). Instead, PE facilitates $\beta_{2} A R$ activation by $\mathrm{G}_{\mathrm{i} 3}$, demonstrating that one type of lipid can exert different effects at the levels of GPCR conformation and GPCR-G protein coupling. For the neurotensin type 1 receptor (NTSR1), increasing nanodisc PG content increases $\mathrm{G}_{\mathrm{q}}$ coupling (Inagaki et al. 2012), whilst decreasing amounts of PG and increasing amounts of a PE-rich brain polar lipid mix in a nanodisc increase the affinity of NTSR 1 for the $G \alpha_{i 1}$ protein (Dijkman and Watts 2015). For the $\beta_{1} A R$, an elegant study established which lipid headgroups and acyl chains direct authentic folding of the receptor upon co-translational insertion into a nanodisc in a cell-free expression system (Rues et al. 2016). Consistently, nanodiscs containing lipids with acidic PG or PS headgroups support greater receptor ligand binding activity, whilst short, $\mathrm{C} 14$ saturated acyl chains support the least activity and C18 acyl chains with one trans double bond support the most activity. For the adenosine $\mathrm{A}_{2 \mathrm{~A}}$ receptor $\left(\mathrm{A}_{2 \mathrm{~A}} \mathrm{R}\right)$, NMR experiments on the nanodiscreconstituted receptor were used to demonstrate that polyunsaturated docosahexaenoic acid (DHA) acyl chains shift the receptor conformational ensemble towards states more productive in $\mathrm{G}$ protein binding, which correlates with greater observed stimulation of $\mathrm{G}_{\mathrm{s}}$ by the receptor in nanodiscs containing DHA chains (Mizumura et al. 2020). Taken together, these studies demonstrate the importance of nanodisc lipid composition on observed receptor activity and highlight the power of nanodiscs as a tool to assess specific lipids for modulatory effects on GPCRs.

Recent studies of GPCRs in nanodiscs using cryo-electron microscopy (cryo-EM) demonstrate the advantages of nanodiscs over detergent solutions for structural studies of GPCRs. For both the M2 muscarinic receptor (M2R) and $\beta_{1}$-adrenergic receptor $\left(\beta_{1} \mathrm{AR}\right)$, reconstitution into POPC/ POPG nanodiscs facilitated coupling to $\beta$-arrestin1, which was weak in detergent (Lee et al. 2020; Staus et al. 2020), consistent with previous indications of a role for acidic phospholipids in arrestin recruitment by GPCRs (Gaidarov et al. 1999; Sommer et al. 2006; Tsukamoto et al. 2010). This in turn allowed for structures of complexes of M2R- $\beta$-arrestin1 (Staus et al. 2020) and $\beta_{1}$ AR- $\beta$-arrestin1 (Lee et al. 2020) to be solved by cryo-EM. In both structures, whilst specific lipid headgroups in the nanodisc are not resolved, it is clear that the C-edge loops of arrestin contact the lipids of the nanodisc, consistent with previous demonstrations of arrestin-lipid interactions by biophysical methods (Lally et al. 2017). Fluorescence experiments on the M2R- $\beta$-arrestin 1 interaction in nanodiscs confirmed that this arrestin-lipid contact is of significance to receptor-arrestin coupling and subsequent functional outcomes (Staus et al. 2020). Together, these structures demonstrate how a nanodisc can support a feature of GPCR signalling that is poorly reconstituted in detergent and illustrate the protein-lipid contacts that are responsible for this detergent sensitivity. Similarly, a structure of a complex of the dopamine D2 receptor (D2R) and the $G_{i}$ heterotrimer was recently obtained using cryo-EM, with the 
receptor reconstituted into an MSP1D1 nanodisc containing POPC, POPG and cholesterol (Yin et al. 2020). Whilst structures of GPCR- $\mathrm{G}_{\mathrm{i}}$ complexes have been obtained in detergents (reviewed in (García-Nafría and Tate 2019; Wang et al. 2020)), this structure demonstrates several interactions between lipids and amino acid residues from both the receptor and $G$ protein. Helix 8 of the receptor is observed buried amongst the headgroup region of the phospholipid bilayer, consistent with biophysical studies (Dijkman et al. 2020) and molecular dynamics simulations (Sensoy and Weinstein 2015). For the $\mathrm{G}$ protein, the $\alpha$-subunit $\alpha \mathrm{N}$ helix runs along the nanodisc surface, residues of the $\gamma$-subunit make polar interactions and unexpectedly, direct contacts between $G \beta$ and the nanodisc bilayer are also observed. This structure therefore shows how reconstitution of a receptor into a nanodisc provides important lipid context to GPCR structures, even when the overall architecture of GPCR- $\mathrm{G}_{\mathrm{i}}$ complexes is known.

Nanodiscs can therefore provide a superior environment for biophysical and structural studies of GPCRs compared to detergents and have provided considerable insight into lipid modulation of GPCRs. However, there are several limitations to the technology and practical aspects to consider for successful nanodisc reconstitution of GPCRs.

The primary issue with nanodiscs is that the reconstitution process requires a detergent-solubilised GPCR. As such, any GPCR that is to be reconstituted into a nanodisc must first pass the gauntlet of detergent solubilisation, which may involve the loss of too much receptor material/activity for the reconstitution to be viable. One solution to this issue is to reconstitute the receptor immediately after membrane solubilisation and before purification and then to purify the receptor from other membrane proteins in nanodiscs; this has been demonstrated for two class B GPCRs (Mitra et al. 2013; Cai et al. 2017). This procedure minimises detergent exposure of the receptor, and limits stripping of functionally important lipids from the receptor by detergent, but does require considerable amounts of MSP, since enough scaffold protein must be present to reconstitute both the target protein and all other membrane proteins solubilised from the membrane into nanodiscs. Another approach is to thermostabilise the receptor sequence to allow detergentsolubilisation and reconstitution. This allows for poorly thermostable receptors to be studied in a more native-like environment but with a significantly different sequence.

An additional limitation of nanodiscs is that the presence of MSP/ApoA-1 in the final nanoparticle can interfere with analysis of the reconstituted GPCR. Since the MSP is a protein, it can produce signals in experiments (e.g. UV spectroscopy, circular dichroism and intrinsic tryptophan fluorescence), which may be difficult to separate from those produced by the reconstituted GPCR.

When undertaking nanodisc reconstitution, there are several parameters that can be varied, and it may be laborious to identify conditions that are optimal for both reconstitution efficiency and receptor activity. Firstly, the receptor should be solubilised in a detergent that both retains significant receptor activity and is simple to remove during nanodisc reconstitution. For example, the popular detergent LMNG has a low critical micellar concentration that means it may be difficult to remove completely during reconstitution (Autzen et al. 2019). Secondly, an appropriate MSP construct and lipid composition should be chosen, and then an optimal MSP/lipid ratio should be determined for reconstitution. MSP1(D1) and MSP1E3D1 have been popular choices for GPCRs (Table 1), forming nanodiscs of approximately $9.7 \mathrm{~nm}$ and $12.1 \mathrm{~nm}$, respectively (Ritchie et al. 2009). The type of lipid(s) chosen is very important, since, as has been discussed, both lipid acyl chain and headgroup composition can modulate receptor activity significantly. Practically, since nanodisc reconstitution is most efficient near the phase transition temperature of the chosen lipids (Ritchie et al. 2009), it is advantageous to choose lipids with phase transitions at $<4{ }^{\circ} \mathrm{C}$, such that reconstitution can be performed at temperatures which preserve receptor activity. The most popular lipid composition reported to date is a POPC/POPG mix (Table 1). Considering the consensus of literature concerning lipid modulation of GPCRs, the inclusion of an acidic lipid will be appropriate in many cases, since acidic lipids have been demonstrated to promote receptor activation (Dawaliby et al. 2016) and coupling of arrestin (Sommer et al. 2006; Lee et al. 2020; Staus et al. 2020), GRKs (Komolov et al. 2017) and certain G proteins (Inagaki et al. 2012; Strohman et al. 2019). In choosing an acidic lipid, PG appears to be more potent than PS in activating the $\beta_{2} \mathrm{AR}$ and is selectively enriched amongst lipids retained by this receptor upon solubilisation (Dawaliby et al. 2016). In addition, acidic phosphatidylinositol(4,5)bisphosphate $\left(\mathrm{PI}(4,5) \mathrm{P}_{2}\right)$ lipids have been shown to play roles in receptor-arrestin interactions (Gaidarov et al. 1999; Huang et al. 2020) and GRK activity (DebBurman et al. 1996). A recent study showed that $\mathrm{PI}(4,5) \mathrm{P}_{2}$ selectively associates with GPCRs and positively modulates NTSR $1-\mathrm{G}_{\mathrm{i}}$ coupling (Yen et al. 2018), whilst association of PI(4,5) $\mathrm{P}_{2}$ with NTSR1 was observed in a recent cryo-EM structure (Huang et al. 2020). In some cases, inclusion of zwitterionic PE lipids may be appropriate, since they have been implicated in receptor- $\mathrm{G}_{\mathrm{i}}$ coupling in several cases (Alves et al. 2005; Dijkman and Watts 2015; Strohman et al. 2019) and can provide direct hydrogen bonds to appropriate receptor residues which are stronger than those with water (Sixl and Watts 1985). Another solution to choosing a lipid composition is to use naturally sourced lipid mixes; for example, porcine brain polar lipids have been successfully used for the $\mu \mathrm{OR}$ and NTSR1 (Kuszak et al. 2009; Dijkman and Watts 2015). However, these lipid mixes may have poorly defined compositions and phase behaviour, and some components may not reconstitute into the nanodisc efficiently (Dijkman and Watts 2015). 
Finally, nanodiscs are limited by the 'bottom-up' nature of the reconstitution process, which requires that the investigator try to reconstruct a functionally supportive lipid composition for the receptor from individual lipid species. It is laborious to exhaustively screen lipids with nanodiscs given the number of possible headgroup and acyl chain structures possible ( 40,000 different lipids are known to date). Even then, lipids that are sufficient to reconstitute/modulate receptor activity in vitro may not necessarily be lipids that act functionally in vivo. It is also apparent that one lipid may have different effects on different aspects of receptor activity; for example, $\mathrm{PE}$ favours an inactive receptor conformation but promotes $\mathrm{G}_{\mathrm{i} 3}$ coupling at the $\beta_{2} \mathrm{AR}$. As a result, there is a need for complementary 'top down' sources of information on GPCR-lipid interactions.

\section{Saposin A nanoparticles}

An emerging alternative technology to MSP nanodiscs/ rHDLs is the 'Salipro' system (Frauenfeld et al. 2016). Similar to nanodiscs, the amphipathic moiety that forms the boundary of the lipid nanoparticle is an $\alpha$-helical protein, saposin A. Unlike MSP, however, there is only a single protein construct used to reconstitute integral membrane proteins of various sizes (Frauenfeld et al. 2016), with saposin A monomers forming a lipid nanoparticle of appropriate size for the membrane protein of interest. To date, the system has seen successful application in membrane protein cryo-EM studies (Du et al. 2020). Using saposin A, a thermostabilised $\beta_{1}$ AR construct was reconstituted with dimyristoyl PC lipids (Chien et al. 2017). The NMR spectrum of the ${ }^{13} \mathrm{C}$-methionine-labelled receptor was sensitive to both ligand and nanobody binding, demonstrating that the receptor retained function in the saposin A nanoparticles. As such, it is clear that this system can be used to study functional GPCRs and may offer a less laborious route to nanoparticle reconstitution than MSP nanodiscs.

\section{Polymer lipid nanoparticles}

The most studied and most frequently used amphipathic polymer for solubilisation and purification of membrane proteins is the styrene-maleic acid co-polymer (SMA), which features hydrophobic styrene and hydrophilic maleic acid moieties that are typically present with gross ratios of 2:1 or 3:1 styrene/ maleic acid (Fig. 3). This amphipathic chemical structure allows the polymer to interact with the hydrophobic portion of lipid bilayers and with aqueous solution, in a role analogous to MSP/ApoA-1 in nanodiscs. However, a key difference is that the polymer is able to produce lipid nanoparticles directly from membranes in a process that requires no detergent.
This occurs in a multi-step mechanism featuring an initial membrane binding step, followed by polymer insertion into the membrane hydrophobic core and finally solubilisation of the membrane into nanoparticles (Scheidelaar et al. 2015). The resulting nanoparticles are referred to as styrene maleic acid lipid particles (SMALPs) or Lipodisqs (Orwick et al. 2012), are typically $\sim 10 \mathrm{~nm}$ in diameter (reviewed in (Dörr et al. 2016)) and contain bilayer structures (Jamshad et al. 2015b). The proteins PagP (Knowles et al. 2009) and bacteriorhodopsin (Knowles et al. 2009; Orwick-Rydmark et al. 2012) were the first membrane proteins to be solubilised, purified with SMA and studied using biophysical methods, with both proteins retaining folding and activity in the resulting nanoparticles. Since these initial demonstrations, several studies have been published in which membrane proteins have been isolated directly from the biological membranes of natural sources or heterologous overexpression systems in the complete absence of detergents (reviewed in (Dörr et al. 2016; Bada Juarez et al. 2019)). The resulting particles have been termed 'native nanodiscs' (Dörr et al. 2016; Autzen et al. 2019) to distinguish them from cases where polymer lipid nanoparticles are formed from proteoliposomes reconstituted from detergent-solubilised proteins.

Several alternative amphipathic polymers have been applied to and developed for membrane protein studies (reviewed in (Bada Juarez et al. 2019)) (Fig. 3). In most cases, this is in response to well-characterised limitations of the SMA polymer. SMA precipitates at low millimolar concentrations of divalent cations (Dörr et al. 2016; Lee et al. 2016b), absorbs strongly in the far-UV region due to the styrene groups (Oluwole et al. 2017b) and has a limited operating $\mathrm{pH}$ range over which it can solubilise membranes (Scheidelaar et al. 2016; Hall et al. 2018). Examples of alternative polymers include DIBMA, which substitutes the styrene moiety for diisobutylene (Oluwole et al. 2017a, b), and SMI, which substitutes maleic acid for a maleimide moiety (Hall et al. 2018), with both polymers being less sensitive to cation-induced precipitation. PMA co-polymers are a third example of alternative polymers and are notable in that their structures are not based on the SMA scaffold (Yasuhara et al. 2017). In all cases, these polymers are capable of producing discoidal bilayers with diameters in the 10-20-nm range and have been used to solubilise and purify specific membrane proteins into nanoparticles from biological membranes (Oluwole et al. 2017a; Barniol-Xicota and Verhelst 2018; Hall et al. 2018; Lavington and Watts 2021).

Since amphipathic polymers can be used to solubilise membrane proteins directly into nanoscale bilayers from biological membranes, they carry considerable potential for the study of GPCRs. Firstly, they negate the need for detergents and their potentially deleterious consequences on receptor stability and function. Secondly, polymers may preserve a lipid environment supportive of receptor function throughout 
SMA

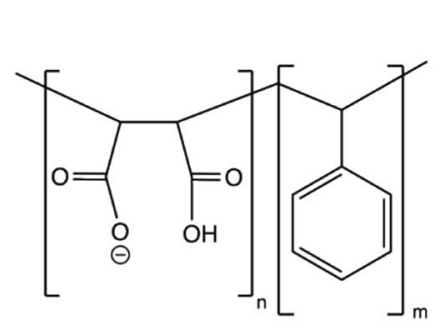

DIBMA

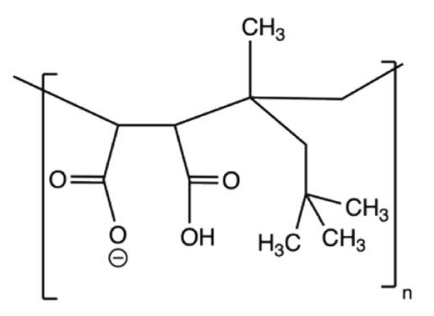

SMI

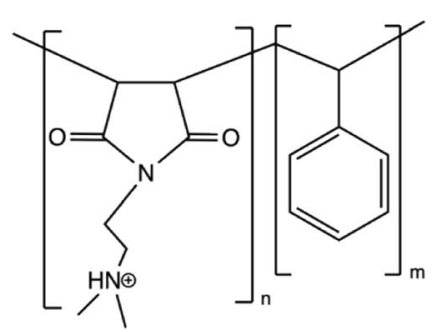

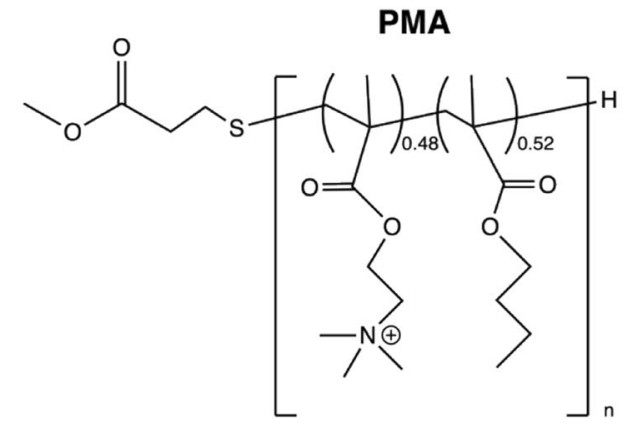

Fig. 3 Structures of amphipathic polymers. The structures of SMA, SMI, DIBMA and PMA are shown

receptor solubilisation and purification and provide opportunities for analysis of this native-like lipid environment. The use of amphipathic polymers to produce GPCR lipid nanoparticles is in its relative infancy when compared to MSP nanodiscs and related technologies. To date, SMA has been used to solubilise several different GPCRs: the $\mathrm{A}_{2 \mathrm{~A}} \mathrm{R}$ (Jamshad et al. 2015a), cannabinoid receptor 1 (CB1R) (Luna et al. 2018), the melatonin-1 receptor $\left(\mathrm{MT}_{1} \mathrm{R}\right)$ (Logez et al. 2016), the growth hormone secretagogue receptor (GHSR) (Logez et al. 2016), a heterodimer of the GHSR and dopamine 2 receptors $\left(D_{2} R\right)$ (Damian et al. 2018) and the dopamine $\mathrm{D} 1$ receptor $\left(\mathrm{D}_{1} \mathrm{R}\right)$ (Bada Juarez et al. 2020) (Table 2). Of these receptors, the $A_{2 A} R, C B 1 R, M_{1} R$ and $\mathrm{D}_{1} \mathrm{R}$ have been purified from biological membranes in the complete absence of detergent using SMA, whilst the GHSR and GHSR-D 2 R complex were solubilised from proteoliposomes.

In all cases of GPCR solubilisation by SMA, some degree of receptor functionality in SMA lipid-nanoparticles has been demonstrated. For the $\mathrm{A}_{2 \mathrm{~A}} \mathrm{R}$ and $\mathrm{D}_{1} \mathrm{R}$, radioligand binding assays produced similar ligand binding profiles in both the original membranes and in the SMA-solubilised material (Jamshad et al. 2015a; Bada Juarez et al. 2020). Subsequent publications using $\mathrm{A}_{2 \mathrm{~A}} \mathrm{R}-\mathrm{SMALPs}$ have also demonstrated ligand binding using fluorescence correlation spectroscopy (Grime et al. 2020) and conformational changes in the receptor caused by inverse agonist binding (Routledge et al. 2020), although in the latter case limited changes were observed upon agonist binding. For the CB1R, authentic folding was confirmed using a conformationally selective antibody (Luna et al. 2018). For the $\mathrm{MT}_{1} \mathrm{R}$, the abilities of the receptor in
SMALPs to couple to $\mathrm{G}$ proteins and recruit arrestin were demonstrated (Logez et al. 2016). For the GHSR, G protein coupling and arrestin recruitment were likewise demonstrated in a SMALP, whilst biophysical techniques revealed a similar ensemble of ligand-dependent conformational states for the receptor whether in a SMALP or in an MSP1E3 nanodisc (Logez et al. 2016). Taken together, these findings suggest that SMALPs provide an environment that supports GPCR function and that solubilisation by SMA does not negatively impact receptor functionality.

GPCRs in SMALPs exhibit improved thermostability compared with GPCRs in detergent solution. $\mathrm{A}_{2 \mathrm{~A}} \mathrm{R}$-SMALPs from Pichia pastoris and HEK293 membranes displayed thermostability increases of $5.5^{\circ}$ and $4^{\circ}$ compared to DDM, respectively, in addition to resistance to multiple freeze-thaw cycles (Jamshad et al. 2015a). Similarly, the GHSR in SMALPs or MSP nanodiscs retained a high degree of specific radioligand binding over the course of a week, versus a significant loss in binding seen for the DDM receptor (Logez et al. 2016). For the CB1R, an increase in thermostability of $\sim 9^{\circ}$ was observed for SMALPs compared to DDM detergent, whilst binding to a conformationally sensitive antibody was resistant to multiple freeze-thaw cycles in SMALPs but not in DDM (Luna et al. 2018). Together with demonstrations of receptor function, these results suggest that SMALPs can provide a superior platform for biophysical and structural studies of GPCR function when compared to detergents.

There is also evidence that SMA solubilisation of GPCRs into lipid nanoparticles can preserve protein-protein interactions between GPCR dimers. A heterodimer of GHSR and $\mathrm{D} 2 \mathrm{R}$ assembled from purified proteins into proteoliposomes 
Table 2 Studies utilising amphipathic polymer lipid nanoparticles to study GPCRs. The type of polymer and membrane source used are shown

\begin{tabular}{|c|c|c|c|c|}
\hline GPCR & Polymer & Membrane source & Comments & Ref \\
\hline $\mathrm{A}_{2 \mathrm{~A}} \mathrm{R}$ & SMA 2:1 & $\begin{array}{l}\text { Pichia pastoris } \\
\text { HEK } 293\end{array}$ & $\begin{array}{l}\text { P. pastoris material purified using } \\
\text { Ni-NTA chromatography }\end{array}$ & $\begin{array}{l}\text { (Jamshad et al. 2015a; Grime } \\
\text { et al. 2020; Routledge et al. } \\
\text { 2020) }\end{array}$ \\
\hline CB1R & SMA 2:1 & $\mathrm{Sf} 9$ & $\begin{array}{l}\text { Material purified by Ni-NTA } \\
\text { chromatography }\end{array}$ & (Luna et al. 2018) \\
\hline $\mathrm{MT}_{1} \mathrm{R}$ & SMA 2:1 & Pichia pastoris & $\begin{array}{l}\text { Purified using Ni-NTA } \\
\text { chromatography and size } \\
\text { exclusion chromatography }\end{array}$ & (Logez et al. 2016) \\
\hline GHSR & SMA 2:1 & $\begin{array}{l}\text { Proteoliposomes, reconstituted } \\
\quad \text { from GHSR expressed in E. coli }\end{array}$ & Purified using Ni-NTA chromatography & “" \\
\hline GHSR- $\mathrm{D}_{2} \mathrm{R}$ heterodimer & SMA 2:1 & $\begin{array}{l}\text { Proteoliposomes reconstituted } \\
\text { from GHSR expressed in E.coli } \\
\text { and } \mathrm{D}_{2} \mathrm{R} \text { expressed in Pichia } \\
\text { pastoris }\end{array}$ & Purified using multiple affinity tags & (Damian et al. 2018) \\
\hline $\mathrm{D}_{1} \mathrm{R}$ & SMA 3:1 & HEK293 & $\begin{array}{l}\text { Purified using size exclusion } \\
\text { chromatography and Ni-NTA } \\
\text { chromatography }\end{array}$ & (Bada Juarez et al. 2020) \\
\hline NTSR1 & PMA & $\mathrm{Sf} 9$ & $\begin{array}{l}\text { Purified using Ni-NTA and } \\
\text { M1-anti FLAG chromatography }\end{array}$ & (Lavington and Watts 2021) \\
\hline $\mathrm{V}_{1 \mathrm{~A}} \mathrm{R}$ & SMI & HEK293 & No purification & (Hall et al. 2018) \\
\hline$\beta_{2} \mathrm{AR}$ & DIBMA & HEK293 & No purification & (Harwood et al. 2020) \\
\hline
\end{tabular}

was solubilised using SMA 2:1 (Damian et al. 2018). The resulting particles were purified using tandem chromatography and displayed robust ligand binding and $\mathrm{G}$ protein activation at each receptor. Whilst this publication relied on a GPCR-GPCR complex formed in model membranes, it nonetheless demonstrates the potential for SMA to isolate similar complexes from biological membranes. Notably, the authors found that low polymer-to-lipid ratios were required to achieve functional heterodimer solubilisation, and the resulting discs were of $\sim 20 \mathrm{~nm}$ in diameter. When more typical polymer-to-lipid ratios were used, 10-12 nm sized discs were produced, but these displayed no G protein coupling activity.

In addition to SMA, the SMI, DIBMA and PMA polymers have recently been applied to solubilisation of GPCRs. The acid-compatible SMI polymer was used to solubilise $\mathrm{A}_{2 \mathrm{~A}} \mathrm{R}$ and vasopressin 1a receptors $\left(\mathrm{V}_{1 \mathrm{a}} \mathrm{R}\right)$ from HEK293 membranes (Hall et al. 2018). Both receptors showed specific binding in radioligand binding assays, although material was not purified. DIBMA has recently been used to solubilise the $\beta_{2} \mathrm{AR}$ from HEK293 membranes. Whilst the material was not purified, detailed analysis of the stability and activity of the receptor in the resulting nanoparticles showed that receptor ligand binding affinity was similar in DIBMA nanoparticles, membranes and detergent, whilst receptor thermostability was improved by $10^{\circ}$ in DIBMA nanoparticles versus detergent (Harwood et al. 2020). We have shown that a polymethacrylate (PMA) co-polymer can be used to solubilise NTSR1 from Sf9 membranes (Lavington and Watts 2021). NTSR1 solubilised with PMA can be purified in the presence of divalent cations, with the resulting material showing stimulation of both $G_{q}$ and $G_{s}$ heterotrimers to a degree that is comparable to higher concentrations of detergent-purified NTSR1.

To date, studies using amphipathic polymers have established that they are a viable means for detergent-free production of functional GPCRs in lipid nanoparticles from yeast, insect and human cell expression systems, which can be analysed by biochemical and biophysical techniques. However, there are a number of practical considerations when using amphipathic polymers for formation of GPCR lipid nanoparticles.

Firstly, as previously discussed, there are well-established limitations of the SMA polymers that may inhibit their application to the solubilisation and purification of GPCRs. Divalent cations such as $\mathrm{Mg}^{2+}$ and $\mathrm{Ca}^{2+}$ which precipitate SMA may be required in buffers for purification or activity assays of GPCRs and may also directly modulate GPCR activity (Ye et al. 2018; Hu et al. 2019). Whilst it is clear that some GPCRs in SMA lipid nanoparticles have been purified using Ni-NTA resins and size exclusion chromatography, there are also reports of non-specific interactions between SMA and such resins, which may hinder purification of the target GPCR (Qiu et al. 2018; Autzen et al. 2019). Others have reported that the source of SMA may play a role in its effectiveness in solubilisation and purification, with some sources being very heterogeneous (Autzen et al. 2019). However, in spite of these limitations, it is clear that SMA can work well for GPCRs, and so it will be pertinent to test in most cases. In cases where SMA is less appropriate, the development of 
alternative polymers has circumvented most of the practical issues of SMA. DIBMA and SMI can both solubilise GPCRs with retention of function into nanoparticles less sensitive to the presence of divalent cations, whilst PMA can solubilise and purify functional NTSR1 in the presence of divalent cations. These studies should therefore pave the way for further use of these newer polymers to study GPCRs, and additional polymers have been reported that have yet to be applied to GPCRs (reviewed in (Bada Juarez et al. 2019)). Given that different polymers may produce nanoparticles of different sizes (Bada Juarez et al. 2019) and may solubilise proteins within different optimal experimental conditions (see below), taken together, SMA and newer polymers constitute a toolkit of polymers that an investigator can screen in a manner similar to different detergents (Autzen et al. 2019).

Irrespective of the kind of polymer used, polymer solubilisation of membranes can be very sensitive to factors such as experimental temperature and salt concentration, so some effort is required to determine optimal conditions for solubilisation and subsequent purification. Studies on simplified model membrane systems show that many variables affect SMA solubilisation kinetics, including properties of the membrane bilayer such as fluidity, lateral pressure and charge density, as well as experimental salt concentration, polymer concentration (Scheidelaar et al. 2015) and pH (Scheidelaar et al. 2016). However, the pattern of behaviour of SMA with respect to biological membranes may vary significantly from studies of model membranes. Indeed, a recent study demonstrated that for SMA solubilisation of the KcsA ion channel overexpressed in Escherichia coli, the pattern of $\mathrm{pH}$ dependence of KcsA solubilisation was quite different to that of model membrane solubilisation at lower polymer concentrations; this is proposed to result from polymer interactions with charged regions of membrane proteins that are absent from model membrane studies (Kopf et al. 2020). Optimal solubilisation of a given membrane will also likely differ for different polymers; for example, the charge properties of PMA are quite distinct from SMA (Fig. 3), and so patterns of salt sensitivity are likely different. Optimal conditions therefore will depend on the polymer chosen, the charge properties of the membrane and the membrane protein being solubilised, and so empirical screening of different salt concentrations, $\mathrm{pH}$ values, temperatures and polymer concentrations for each polymer to be tested is highly recommended. It should also be noted that ideal solubilisation conditions for a receptor may not translate to optimal purification conditions for that receptor, especially if excess free polymer is present (Kopf et al. 2020), and so dialysis/buffer-exchange steps may be required before purification of solubilised material.

Finally, there are still aspects of the physical characteristics of polymer lipid nanoparticles that are unclear. Some studies have shown that rapid exchange of lipids between individual SMA and DIBMA lipid nanoparticles is possible (Hazell et al.
2016; Cuevas Arenas et al. 2017; Danielczak and Keller 2018), suggesting that these particles are rather more dynamic than MSP nanodiscs (Denisov and Sligar 2017) and that polymers do not act as simple 'cookie cutters' at the membrane. GPCR-lipid interactions preserved in SMA lipid nanoparticles may not therefore represent the precise lipid environment surrounding the GPCR prior to solubilisation. Given that exchange of lipids within a bilayer is much faster than the observed exchange between bilayers within nanoparticles (Marsh and Watts 1981) and that there is potential for specific association between lipids and membrane proteins (Watts 1993), strong protein-lipid interactions will presumably be preserved during the collisional exchange process, but weaker interactions may be lost (Cuevas Arenas et al. 2017). It is not yet clear whether collisional exchange is a general feature of all types of polymer lipid nanoparticle. SMALPs also have a broader bilayer phase transition than lipid bilayers in a dispersion (Orwick et al. 2012) or indeed in an MSP nanodisc (Denisov et al. 2005), although this effect is less pronounced PMA lipid nanoparticles (Yasuhara et al. 2017) and DIBMA lipid nanoparticles (Oluwole et al. 2017a). In SMALPs, the extent of interaction between lipids and the surrounding polymer is therefore likely higher than between lipid and MSP in a nanodisc. It is also not clear what controls particle diameter in polymer nanoparticles, with a range of particle diameters reported (reviewed in (Dörr et al. 2016)). Relatedly, the number of lipids in a lipid-polymer nanoparticle may be highly variable, with reports of as few as 11 lipids in PagP SMA lipid nanoparticles (Knowles et al. 2009). Indeed, a cryo-EM structure of an alternative complex III supercomplex in an SMA nanoparticle showed a very thin layer of lipid surrounding the protein (Sun et al. 2018), with the boundary of the particle following the shape of the complex, suggesting that under some conditions a true lipid bilayer may not form in an SMA nanoparticle.

\section{Discussion and perspectives}

It should first be noted that despite the advantages of both lipid nanoparticle technologies in providing lipid context to GPCR studies, detergents clearly play an important role in studies of GPCRs. Detergent solubilisation is a necessary step in nanodisc reconstitution, and if a receptor is stable and demonstrates the desired functionality in detergent, then, depending on the question to be addressed, reconstitution into nanodiscs or attempts at detergent-free purification with polymers may be harder to justify. In some cases, if there is prior information regarding functionally important lipids, it may be possible to re-introduce specific lipids in detergent-solubilised form to improve the function of the receptor. Such an approach was successful for a recent cryo-EM structure of the NTSR1- $\beta$ arrestin1 complex (Huang et al. 2020), which did not require 
the use of nanodiscs and in which $\mathrm{PI}(4,5) \mathrm{P}_{2}$ added during complexing was observed bound to the receptor. Nonetheless, there is increasing appreciation of the importance of the lipid environment in structural and biophysical studies of GPCRs, and as the amount of literature published in this area increases, it is anticipated that detergent studies will be increasingly complemented by studies in lipidic environments such as nanodiscs and polymer lipid nanoparticles.

Nanodiscs and rHDLs represent a well-validated means to study GPCRs in a defined and experimentally tractable lipid environment. This nanodisc environment can support higher receptor activity than detergents and allow for receptor functions that benefit from the absence of detergent, the presence of a bilayer structure, the presence of specific modulatory lipids or a combination of these factors. Nanodiscs have proved an excellent means for assessing the roles of specific lipids on GPCR function and have added considerable detail to the literature on GPCR-lipid interactions. Conversely, the need to reconstitute functionally supportive lipid environments in a bottom-up manner means that we must be cautious to assume that the lipids chosen necessarily reflect important/ annular lipids in vivo, and optimisation of nanodisc reconstitution may be laborious. Saposin A nanoparticles may offer a viable alternative to MSP nanodiscs in such cases. Typically, nanodisc reconstitution will be most suitable for receptors that are stable in detergent, and thermostabilisation of the receptor sequence may be required to achieve this. Moving forward, techniques such as native mass spectrometry may be able to provide complementary 'top-down' information on GPCRlipid interactions; a recent study clearly identified lipids that associate with several different GPCRs after solubilisation (Yen et al. 2018), and in theory, the technique can discriminate between very similar lipids bound to a membrane protein (Gault et al. 2016).

Polymer lipid nanoparticles can potentially overcome the disadvantages of nanodiscs, namely, they can be formed without detergents and rely on the receptor itself to organise its lipid environment rather than the experimentalist. Reports to date show at least four kinds of polymer can be used to solubilise functional GPCRs, and the potential advantages of polymerlipid nanoparticles for studies of GPCRs clearly justify further use of these systems. Firstly, they can potentially allow poorly thermostable receptors to be studied in lipid environments without need for thermostabilising mutations of the receptor sequence, by negating the need for the detergents. Secondly, polymer-lipid nanoparticles can potentially preserve nativelike protein-protein and protein-lipid interactions which would otherwise be perturbed by detergents. The demonstration that SMA can solubilise a GPCR heterodimer from liposomes suggests that it may be possible to isolate complexes of GPCRs with other integral or peripheral membrane proteins formed in biological membranes without detergents. Likewise, it is possible to analyse the lipid content of protein-containing polymer lipid nanoparticles (Dörr et al. 2014; Prabudiansyah et al. 2015; Teo et al. 2019), and cryo-EM structures of bacterial membrane proteins in SMA lipid nanoparticles show well-ordered lipid molecules (Qiu et al. 2018; Sun et al. 2018), suggesting polymers may provide a productive route to information on GPCRlipid interactions. It is probably incorrect to assume that polymers always act like molecular 'cookie cutters' that faithfully capture the lipid environment that surrounds a GPCR in a biological membrane, since collisional exchange of lipids for SMA and DIBMA nanoparticles is possible, but it seems likely that even in such cases functionally important lipids are retained. The current practical limitations of the polymer approach over MSP nanodiscs generally stem from the novelty of the technology; the number of publications using polymers to form lipid nanoparticles is rapidly increasing, and it is anticipated that wider adoption of the technology, as well as application of newer polymers, will allow the technology and its application to GPCRs to be optimised.

Acknowledgements We thank the Medical Research Council (UK) for a studentship to SL.

\section{Compliance with ethical standards}

Conflict of interest The authors declare that they have no conflict of interest.

Open Access This article is licensed under a Creative Commons Attribution 4.0 International License, which permits use, sharing, adaptation, distribution and reproduction in any medium or format, as long as you give appropriate credit to the original author(s) and the source, provide a link to the Creative Commons licence, and indicate if changes were made. The images or other third party material in this article are included in the article's Creative Commons licence, unless indicated otherwise in a credit line to the material. If material is not included in the article's Creative Commons licence and your intended use is not permitted by statutory regulation or exceeds the permitted use, you will need to obtain permission directly from the copyright holder. To view a copy of this licence, visit http://creativecommons.org/licenses/by/4.0/.

\section{References}

Adamson RJ, Watts A (2014) Kinetics of the early events of GPCR signalling. FEBS Lett 588:4701-4707. https://doi.org/10.1016/j. febslet.2014.10.043

Álvarez R, López DJ, Casas J et al (2015) G protein-membrane interactions I: G $\alpha$ il myristoyl and palmitoyl modifications in protein-lipid interactions and its implications in membrane microdomain localization. Biochim Biophys Acta Mol Cell Biol Lipids 1851:15111520. https://doi.org/10.1016/j.bbalip.2015.08.001

Alves ID, Salgado GFJ, Salamon Z et al (2005) Phosphatidylethanolamine enhances rhodopsin photoactivation and transducin binding in a solid supported lipid bilayer as determined using plasmon-waveguide resonance spectroscopy. Biophys J 88:198-210. https://doi.org/10.1529/ biophysj.104.046722

Autzen HE, Julius D, Cheng Y (2019) Membrane mimetic systems in CryoEM: keeping membrane proteins in their native environment. 
Curr Opin Struct Biol 52:1-10. https://doi.org/10.1016/j.sbi.2019.05. 022

Bada Juarez JF, Harper AJ, Judge PJ et al (2019) From polymer chemistry to structural biology: the development of SMA and related amphipathic polymers for membrane protein extraction and solubilisation. Chem Phys Lipids 221:167-175. https://doi.org/10.1016/j. chemphyslip.2019.03.008

Bada Juarez JF, Muñoz-García JC, Inácio dos Reis R et al (2020) Detergent-free extraction of a functional low-expressing GPCR from a human cell line. Biochim Biophys Acta Biomembr 1862: 183152. https://doi.org/10.1016/j.bbamem.2019.183152

Bae HE, Mortensen JS, Ribeiro O et al (2016) Tandem neopentyl glycol maltosides (TNMs) for membrane protein stabilisation. Chem Commun 52:12104-12107. https://doi.org/10.1039/c6cc06147h

Bae HE, Du Y, Hariharan P et al (2019) Asymmetric maltose neopentyl glycol amphiphiles for a membrane protein study: effect of detergent asymmetricity on protein stability. Chem Sci 10:1107-1116. https:// doi.org/10.1039/c8sc02560f

Barniol-Xicota M, Verhelst SHL (2018) Stable and functional rhomboid proteases in lipid nanodiscs by using diisobutylene/maleic acid copolymers. J Am Chem Soc 140:14557-14561. https://doi.org/10. 1021/jacs. 8 b08441

Bayburt TH, Grinkova YV, Sligar SG (2002) Self-assembly of discoidal phospholipid bilayer nanoparticles with membrane scaffold proteins. Nano Lett 2:853-856

Bayburt TH, Vishnivetskiy SA, McLean MA et al (2011) Monomeric rhodopsin is sufficient for normal rhodopsin kinase (GRK1) phosphorylation and arrestin-1 binding. J Biol Chem 286:1420-1428. https://doi.org/10.1074/jbc.M110.151043

Berkamp S, Park SH, De Angelis AA et al (2017) Structure of monomeric Interleukin- 8 and its interactions with the $\mathrm{N}$-terminal binding site-I of CXCR1 by solution NMR spectroscopy. J Biomol NMR 69:111121. https://doi.org/10.1007/s10858-017-0128-3

Bocquet N, Kohler J, Hug MN et al (2015) Real-time monitoring of binding events on a thermostabilized human A2A receptor embedded in a lipid bilayer by surface plasmon resonance. Biochim Biophys Acta Biomembr 1848:1224-1233. https://doi.org/10. 1016/j.bbamem.2015.02.014

Bubis J (1998) Effect of detergents and lipids on transducin photoactivation by rhodopsin. Biol Res 31:59-71

Cai Y, Liu Y, Culhane KJ et al (2017) Purification of family B G proteincoupled receptors using nanodiscs: application to human glucagonlike peptide-1 receptor. PLoS One 12:1-18. https://doi.org/10.1371/ journal.pone. 0179568

Casiraghi M, Damian M, Lescop E et al (2016) Functional modulation of a $\mathrm{G}$ protein-coupled receptor conformational landscape in a lipid bilayer. J Am Chem Soc 138:11170-11175. https://doi.org/10. 1021/jacs.6b04432

Chien CTH, Helfinger LR, Bostock MJ et al (2017) An adaptable phospholipid membrane mimetic system for solution NMR studies of membrane proteins. J Am Chem Soc 139:14829-14832. https:// doi.org/10.1021/jacs.7b06730

Chung KY, Day PW, Vélez-Ruiz G et al (2013) Identification of GPCRinteracting cytosolic proteins using HDL particles and mass spectrometry-based proteomic approach. PLoS One 8:1-9. https:// doi.org/10.1371/journal.pone.0054942

Crouthamel M, Thiyagarajan MM, Evanko DS, Wedegaertner PB (2008) $\mathrm{N}$-terminal polybasic motifs are required for plasma membrane localization of $\mathrm{G} \alpha \mathrm{s}$ and $\mathrm{G} \alpha \mathrm{q}$. Cell Signal 20:1900-1910. https://doi. org/10.1016/j.cellsig.2008.06.019

Cuevas Arenas R, Danielczak B, Martel A et al (2017) Fast collisional lipid transfer among polymer-bounded nanodiscs. Sci Rep 7:45875. https://doi.org/10.1038/srep45875

Damian M, Marie J, Leyris JP et al (2012) High constitutive activity is an intrinsic feature of ghrelin receptor protein: a study with a functional monomeric GHS-R1a receptor reconstituted in lipid discs. J Biol Chem 287:3630-3641. https://doi.org/10.1074/jbc.M111.288324

Damian M, Pons V, Renault P et al (2018) GHSR-D2R heteromerization modulates dopamine signaling through an effect on $\mathrm{G}$ protein conformation. Proc Natl Acad Sci U S A 115:4501-4506. https://doi. org/10.1073/pnas.1712725115

Damian M, Mary S, Maingot M et al (2015) Ghrelin receptor conformational dynamics regulate the transition from a preassembled to an active receptor: Gq complex. Proc Natl Acad Sci U S A 112:16011606. https://doi.org/10.1073/pnas.1414618112

Danielczak B, Keller S (2018) Collisional lipid exchange among DIBMA-encapsulated nanodiscs (DIBMALPs). Eur Polym J 109: 206-213. https://doi.org/10.1016/j.eurpolymj.2018.09.043

Das M, Du Y, Mortensen JS et al (2019) Trehalose-cored amphiphiles for membrane protein stabilization: importance of the detergent micelle size in GPCR stability. Org Biomol Chem 17:3249-3257. https:// doi.org/10.1039/c8ob03153c

Dawaliby R, Trubbia C, Delporte C et al (2016) Allosteric regulation of G protein-coupled receptor activity by phospholipids. Nat Chem Biol 12:35-39. https://doi.org/10.1038/nchembio.1960

DebBurman SK, Ptasienski J, Benovic JL, Hosey MM (1996) G proteincoupled receptor kinase GRK2 is a phospholipid-dependent enzyme that can be conditionally activated by $\mathrm{G}$ protein $\beta \gamma$ subunits. J Biol Chem 271:22552-22562. https://doi.org/10.1074/jbc.271.37.22552

Denisov IG, Grinkova YV, Lazarides AA, Sligar SG (2004) Directed self-assembly of monodisperse phospholipid bilayer nanodiscs with controlled size. J Am Chem Soc 126:3477-3487. https://doi.org/10. $1021 / \mathrm{ja} 0393574$

Denisov IG, Sligar SG (2017) Nanodiscs in membrane biochemistry and biophysics. Chem Rev 117:4669-4713. https://doi.org/10.1021/acs. chemrev.6b00690

Denisov IG, McLean MA, Shaw AW et al (2005) Thermotropic phase transition in soluble nanoscale lipid bilayers. J Phys Chem B 109: 15580-15588. https://doi.org/10.1021/jp051385g

Dijkman PM, Watts A (2015) Lipid modulation of early G proteincoupled receptor signalling events. Biochim Biophys Acta Biomembr 1848:2889-2897. https://doi.org/10.1016/j.bbamem. 2015.08.004

Dijkman PM, Muñoz-García JC, Lavington SR et al (2020) Conformational dynamics of a $\mathrm{G}$ protein-coupled receptor helix 8 in lipid membranes. Sci Adv 6:1-14. https://doi.org/10.1126/sciadv. aav8207

Dodevski I, Plückthun A (2011) Evolution of three human GPCRs for higher expression and stability. J Mol Biol 408:599-615. https://doi. org/10.1016/j.jmb.2011.02.051

Dörr JM, Koorengevel MC, Schäfer M et al (2014) Detergent-free isolation, characterization, and functional reconstitution of a tetrameric $\mathrm{K}+$ channel: the power of native nanodiscs. Proc Natl Acad Sci U S A 111:18607-18612. https://doi.org/10.1073/pnas.1416205112

Dörr JM, Scheidelaar S, Koorengevel MC et al (2016) The styrenemaleic acid copolymer: a versatile tool in membrane research. Eur Biophys J 45:3-21. https://doi.org/10.1007/s00249-015-1093-y

Dorsam RT, Gutkind JS (2007) G-protein-coupled receptors and cancer. Nat Rev Cancer 7:79-94. https://doi.org/10.1038/nrc2069

Downes GB, Gautam N (1999) The G protein subunit gene families. Genomics 62:544-552. https://doi.org/10.1006/geno.1999.5992

Du D, Neuberger A, Orr MW et al (2020) Interactions of a bacterial RND transporter with a transmembrane small protein in a lipid environment. Structure 28:625-634.e6. https://doi.org/10.1016/j.str.2020. 03.013

El Moustaine D, Granier S, Doumazane E et al (2012) Distinct roles of metabotropic glutamate receptor dimerization in agonist activation and G-protein coupling. Proc Natl Acad Sci U S A 109:1634216347. https://doi.org/10.1073/pnas.1205838109 
Frauenfeld J, Löving R, Armache J et al (2016) A saposin-lipoprotein nanoparticle system for membrane proteins. Nat Methods 13:345351. https://doi.org/10.1038/nmeth.3801

Fredriksson R, Lagerström MC, Lundin L-G, Schiöth HB (2003) The Gprotein-coupled receptors in the human genome form five main families. Phylogenetic analysis, paralogon groups, and fingerprints. Mol Pharmacol 63:1256-1272. https://doi.org/10.1124/mol.63.6. 1256

Gaidarov I, Krupnick JG, Falck JR et al (1999) Arrestin function in G protein-coupled receptor endocytosis requires phosphoinositide binding. EMBO J 18:871-881. https://doi.org/10.1093/emboj/18.4. 871

Gao T, Petrlova J, He W et al (2012) Characterization of de novo synthesized GPCRs supported in nanolipoprotein discs. PLoS One 7:5-12. https://doi.org/10.1371/journal.pone.0044911

García-Nafría J, Tate CG (2019) Cryo-EM structures of GPCRs coupled to Gs, Gi and Go. Mol Cell Endocrinol 488:1-13. https://doi.org/10. 1016/j.mce.2019.02.006

Gault J, Donlan JAC, Liko I et al (2016) High-resolution mass spectrometry of small molecules bound to membrane proteins. Nat Methods 13:333-336. https://doi.org/10.1038/nmeth.3771

Goddard AD, Dijkman PM, Adamson RJ et al (2015) Reconstitution of membrane proteins: a GPCR as an example. Methods Enzymol 556: 405-424

Gregorio GG, Masureel M, Hilger D et al (2017) Single-molecule analysis of ligand efficacy in $\beta 2$ AR-G-protein activation. Nature 547: 68-73. https://doi.org/10.1038/nature22354

Grime RL, Goulding J, Uddin R et al (2020) Single molecule binding of a ligand to a G-protein-coupled receptor in real time using fluorescence correlation spectroscopy, rendered possible by nanoencapsulation in styrene maleic acid lipid particles. Nanoscale 12: 11518-11525. https://doi.org/10.1039/d0nr01060j

Grisshammer R (2009) Purification of recombinant G-protein-coupled receptors. Methods Enzymol 463:631-645. https://doi.org/10. 1016/S0076-6879(09)63036-6

Hall SCL, Tognoloni C, Charlton J et al (2018) An acid-compatible copolymer for the solubilization of membranes and proteins into lipid bilayer-containing nanoparticles. Nanoscale 10:10609-10619. https://doi.org/10.1039/c8nr01322e

Harwood C, Sykes DA, Hoare B, et al (2020) Functional solubilisation of the $\beta 2$-adrenoceptor $(\beta 2 \mathrm{AR})$ using diisobutylene maleic acid (DIBMA). bioRxiv. https://doi.org/10.1101/2020.06.29.171512

Hauser AS, Attwood MM, Rask-Andersen M et al (2017) Trends in GPCR drug discovery: new agents, targets and indications. Nat Rev Drug Discov 16:829-842. https://doi.org/10.1038/nrd.2017. 178

Hazell G, Arnold T, Barker RD et al (2016) Evidence of lipid exchange in styrene maleic acid lipid particle (SMALP) nanodisc systems. Langmuir 32:11845-11853. https://doi.org/10.1021/acs.langmuir. $6 \mathrm{~b} 02927$

Hu X, Provasi D, Filizola M (2019) Mechanism of $\mu$-opioid receptormagnesium interaction and positive allosteric modulation. Biophys J 118:1-13. https://doi.org/10.1101/689612

Huang Y, Todd N, Thathiah A (2017) The role of GPCRs in neurodegenerative diseases: avenues for therapeutic intervention. Curr Opin Pharmacol 32:96-110. https://doi.org/10.1016/j.coph.2017.02.001

Huang W, Masureel M, Qu Q et al (2020) Structure of the neurotensin receptor 1 in complex with $\beta$-arrestin 1 . Nature 579:303-308. https://doi.org/10.1038/s41586-020-1953-1

Inagaki S, Ghirlando R, White JF et al (2012) Modulation of the interaction between neurotensin receptor NTS1 and Gq protein by lipid. J Mol Biol 417:95-111. https://doi.org/10.1016/j.jmb.2012.01.023

Inagaki S, Ghirlando R, Vishnivetskiy SA et al (2015) G protein-coupled receptor kinase 2 (GRK2) and 5 (GRK5) exhibit selective phosphorylation of the neurotensin receptor in vitro. Biochemistry 54:4320 4329. https://doi.org/10.1021/acs.biochem.5b00285
Jamshad M, Charlton J, Lin Y et al (2015a) G-protein coupled receptor solubilization and purification for biophysical analysis and functional studies, in the total absence of detergent. Biosci Rep 35:1-10. https://doi.org/10.1042/BSR20140171

Jamshad M, Grimard V, Idini I et al (2015b) Structural analysis of a nanoparticle containing a lipid bilayer used for detergent-free extraction of membrane proteins. Nano Res 8:774-789. https://doi.org/10. 1007/s12274-014-0560-6

Jastrzebska B, Goc A, Golczak M, Palczewski K (2009) Phospholipids are needed for the proper formation, stability, and function of the photoactivated rhodopsin-transducin complex. Biochemistry 48: 5159-5170. https://doi.org/10.1021/bi900284x

Knowles TJ, Finka R, Smith C et al (2009) Membrane proteins solubilized intact in lipid containing nanoparticles bounded by styrene maleic acid copolymer. J Am Chem Soc 131:7484-7485. https:// doi.org/10.1021/ja810046q

Koehl A, Hu H, Feng D et al (2019) Structural insights into the activation of metabotropic glutamate receptors. Nature 566:79-84. https://doi. org/10.1038/s41586-019-0881-4

Kofuku Y, Ueda T, Okude J et al (2014) Functional dynamics of deuterated $\beta 2$-adrenergic receptor in lipid bilayers revealed by NMR spectroscopy. Angew Chem Int Ed 53:13376-13379. https://doi. org/10.1002/anie.201406603

Komolov KE, Du Y, Duc NM et al (2017) Structural and functional analysis of a $\beta 2$-adrenergic receptor complex with GRK5. Cell 169:407-421. https://doi.org/10.1016/j.cell.2017.03.047

Kopf AH, Dörr JM, Koorengevel MC et al (2020) Factors influencing the solubilization of membrane proteins from Escherichia coli membranes by styrene-maleic acid copolymers. Biochim Biophys Acta Biomembr 1862:183125. https://doi.org/10.1016/j.bbamem.2019. 183125

Kosloff M, Alexov E, Arshavsky VY, Honig B (2008) Electrostatic and lipid anchor contributions to the interaction of transducin with membranes. J Biol Chem 283:31197-31207. https://doi.org/10.1074/jbc. M803799200

Kubota M, Tanaka T, Kohno T, Wakamatsu K (2009) GDP-GTP exchange processes of G $\alpha$ il protein are accelerated/ decelerated depending on the type and the concentration of added detergents. $\mathrm{J}$ Biochem 146:875-880. https://doi.org/10.1093/jb/mvp132

Kuszak AJ, Pitchiaya S, Anand JP et al (2009) Purification and functional reconstitution of monomeric $\mu$-opioid receptors. Allosteric modulation of agonists binding by Gi2. J Biol Chem 284:26732-26741. https://doi.org/10.1074/jbc.M109.026922

Lally CCM, Bauer B, Selent J, Sommer ME (2017) C-edge loops of arrestin function as a membrane anchor. Nat Commun 8:14258. https://doi.org/10.1038/ncomms14258

Lamichhane R, Liu JJ, Pljevaljcic G et al (2015) Single-molecule view of basal activity and activation mechanisms of the $\mathrm{G}$ protein-coupled receptor $\beta 2$ AR. Proc Natl Acad Sci U S A 112:14254-14259. https://doi.org/10.1073/pnas.1519626112

Latorraca NR, Venkatakrishnan AJ, Dror RO (2017) GPCR dynamics: structures in motion. Chem Rev 117:139-155. https://doi.org/10. 1021/acs.chemrev.6b00177

Lavington S, Watts A (2021) Detergent-free solubilisation \& purification of a $\mathrm{G}$ protein coupled receptor using a polymethacrylate polymer. Biochim Biophys Acta Biomembr 1863:183441. https://doi.org/10. 1016/j.bbamem.2020.183441

Lee S, Mao A, Bhattacharya S et al (2016a) How do short chain nonionic detergents destabilize G-protein-coupled receptors? J Am Chem Soc 138:15425-15433. https://doi.org/10.1021/jacs.6b08742

Lee SC, Knowles TJ, Postis VLG et al (2016b) A method for detergentfree isolation of membrane proteins in their local lipid environment. Nat Protoc 11:1149-1162. https://doi.org/10.1038/nprot.2016.070

Lee Y, Warne T, Nehmé R et al (2020) Molecular basis of $\beta$-arrestin coupling to formoterol-bound $\beta 1$-adrenoceptor. Nature 583:862 866. https://doi.org/10.1038/s41586-020-2419-1 
Leitz AJ, Bayburt TH, Barnakov AN et al (2006) Functional reconstitution of beta-2-adrenergic receptors utilizing self-assembling Nanodisc technology. Biotechniques 40:601-612. https://doi.org/ 10.2144/000112169

Liu JJ, Horst R, Katritch V et al (2012) Biased signaling pathways in $\beta 2$ adrenergic receptor characterized by 19F-NMR. Science 335:11061111. https://doi.org/10.1126/science. 1215802

Logez C, Damian M, Legros C et al (2016) Detergent-free isolation of functional $\mathrm{G}$ protein-coupled receptors into nanometric lipid particles. Biochemistry 55:38-48. https://doi.org/10.1021/acs.biochem. $5 \mathrm{~b} 01040$

Luna VM, Vazir M, Vaish A et al (2018) Generation of membrane proteins in polymer-based lipoparticles as flow cytometry antigens. Eur Polym J 109:483-488. https://doi.org/10.1016/j.eurpolymj.2018.10. 017

Manglik A, Kruse AC (2017) Structural basis for G protein-coupled receptor activation. Biochemistry 56:5628-5634. https://doi.org/ 10.1021/acs.biochem.7b00747

Manglik A, Kim TH, Masureel M et al (2015) Structural insights into the dynamic process of $\beta 2$-adrenergic receptor signaling. Cell 161: 1101-1111. https://doi.org/10.1016/j.cell.2015.04.043

Marsh D, Watts A (1981) ESR spin-label studies of liposomes. In: Knight CG (ed) liposomes: from physical structure to therapeutic applications. Elsevier, pp 139-186

Mary S, Damian M, Louet M et al (2012) Ligands and signaling proteins govern the conformational landscape explored by a $\mathrm{G}$ proteincoupled receptor. Proc Natl Acad Sci U S A 109:8304-8309. https://doi.org/10.1073/pnas.1119881109

Mitra N, Liu Y, Liu J et al (2013) Calcium-dependent ligand binding and g-protein signaling of family B GPCR parathyroid hormone 1 receptor purified in nanodiscs. ACS Chem Biol 8:617-625. https:// doi.org/10.1021/cb300466n

Mizumura T, Kondo K, Kurita M et al (2020) Activation of adenosine A2A receptor by lipids from docosahexaenoic acid revealed by NMR. Sci Adv 6:1-15. https://doi.org/10.1126/sciadv.aay8544

Munk C, Mutt E, Isberg V et al (2019) An online resource for GPCR structure determination and analysis. Nat Methods 16:151-162. https://doi.org/10.1038/s41592-018-0302-x

Nasr ML, Wagner G (2018) Covalently circularized nanodiscs; challenges and applications. Curr Opin Struct Biol 51:129-134. https:// doi.org/10.1016/j.sbi.2018.03.014

Nasr ML, Baptista D, Strauss M et al (2016) Covalently circularized nanodiscs for studying membrane proteins and viral entry. Nat Methods 14:49-52. https://doi.org/10.1038/nmeth.4079

Nygaard R, Zou Y, Dror RO et al (2013) The dynamic process of $\beta 2$ adrenergic receptor activation. Cell 152:532-542. https://doi.org/10. 1016/j.cell.2013.01.008

Oates J, Watts A (2011) Uncovering the intimate relationship between lipids, cholesterol and GPCR activation. Curr Opin Struct Biol 21: 802-807. https://doi.org/10.1016/j.sbi.2011.09.007

Oates J, Faust B, Attrill H et al (2012) The role of cholesterol on the activity and stability of neurotensin receptor 1 . Biochim Biophys Acta 1818:2228-2233. https://doi.org/10.1016/j.bbamem.2012.04. 010

Oluwole AO, Danielczak B, Meister A et al (2017a) Solubilization of membrane proteins into functional lipid-bilayer nanodiscs using a diisobutylene/maleic acid copolymer. Angew Chem Int Ed 56: 1919-1924. https://doi.org/10.1002/anie.201610778

Oluwole AO, Klingler J, Danielczak B et al (2017b) Formation of lipidbilayer nanodiscs by diisobutylene/maleic acid (DIBMA) copolymer. Langmuir 33:14378-14388. https://doi.org/10.1021/acs. langmuir. $7 \mathrm{~b} 03742$

Onorato JJ, Gillis ME, Liu Y et al (1995) The $\beta$-adrenergic receptor kinase (GRK2) is regulated by phospholipids. J Biol Chem 270: 21346-21353. https://doi.org/10.1074/jbc.270.36.21346
Orwick MC, Judge PJ, Procek J et al (2012) Detergent-free formation and physicochemical characterization of nanosized lipid-polymer complexes: Lipodisq. Angew Chem Int Ed 51:4653-4657. https://doi. org/10.1002/anie.201201355

Orwick-Rydmark M, Lovett JE, Graziadei A et al (2012) Detergent-free incorporation of a seven-transmembrane receptor protein into nanosized bilayer Lipodisq particles for functional and biophysical studies. Nano Lett 12:4687-4692. https://doi.org/10.1021/ nl3020395

Pierce KL, Premont RT, Lefkowitz RJ (2002) Seven-transmembrane receptors. Nat Rev Mol Cell Biol 3:639-650. https://doi.org/10.1038/ nrm908

Pitcher JA, Fredericks ZL, Carl Stone W et al (1996) Phosphatidylinositol 4,5-bisphosphate (PIP2)-enhanced G protein- coupled receptor kinase (GRK) activity. Location, structure, and regulation of the PIP2 binding site distinguishes the GRK families. J Biol Chem 271: 24907-24913. https://doi.org/10.1074/jbc.271.40.24907

Prabudiansyah I, Kusters I, Caforio A, Driessen AJM (2015) Characterization of the annular lipid shell of the Sec translocon. Biochim Biophys Acta Biomembr 1848:2050-2056. https://doi. org/10.1016/j.bbamem.2015.06.024

Qiu W, Fu Z, Xu GG et al (2018) Structure and activity of lipid bilayer within a membrane-protein transporter. Proc Natl Acad Sci U S A 115:12985-12990. https://doi.org/10.1073/pnas.1812526115

Rasmussen SGF, Choi HJ, Fung JJ et al (2011) Structure of a nanobodystabilized active state of the $\beta 2$ adrenoceptor. Nature 469:175-181. https://doi.org/10.1038/nature09648

Redka DS, Morizumi T, Elmslie G et al (2014) Coupling of G proteins to reconstituted monomers and tetramers of the M2 muscarinic receptor. J Biol Chem 289:24347-24365. https://doi.org/10.1074/jbc. M114.559294

Reiter E, Lefkowitz RJ (2006) GRKs and $\beta$-arrestins: roles in receptor silencing, trafficking and signaling. Trends Endocrinol Metab 17: $159-165$

Riddy DM, Delerive P, Summers RJ et al (2018) G protein-coupled receptors targeting insulin resistance, obesity, and type 2 diabetes mellitus. Pharmacol Rev 70:39-67. https://doi.org/10.1124/pr.117. 014373

Ritchie TK, Grinkova YV, Bayburt TH et al (2009) Chapter 11 reconstitution of membrane proteins in phospholipid bilayer nanodiscs. Methods Enzymol 464:211-231. https://doi.org/10.1016/S00766879(09)64011-8

Routledge SJ, Jamshad M, Little HA et al (2020) Ligand-induced conformational changes in a SMALP-encapsulated GPCR. Biochim Biophys Acta Biomembr 1862:183235. https://doi.org/10.1016/j. bbamem.2020.183235

Rues RB, Dötsch V, Bernhard F (2016) Co-translational formation and pharmacological characterization of beta1-adrenergic receptor/ nanodisc complexes with different lipid environments. Biochim Biophys Acta Biomembr 1858:1306-1316. https://doi.org/10. 1016/j.bbamem.2016.02.031

Sarvazyan NA, Remmers AE, Neubig RR (1998) Determinants of Gilalpha and beta gamma binding. Measuring high affinity interactions in a lipid environment using flow cytometry. J Biol Chem 273: 7934-7940. https://doi.org/10.1074/jbc.273.14.7934

Scheidelaar S, Koorengevel MC, Pardo JD et al (2015) Molecular model for the solubilization of membranes into nanodisks by styrene maleic acid copolymers. Biophys J 108:279-290. https://doi.org/10. 1016/j.bpj.2014.11.3464

Scheidelaar S, Koorengevel MC, van Walree CA et al (2016) Effect of polymer composition and $\mathrm{pH}$ on membrane solubilization by styrene-maleic acid copolymers. Biophys J 111:1974-1986. https://doi.org/10.1016/j.bpj.2016.09.025

Sensoy O, Weinstein H (2015) A mechanistic role of Helix 8 in GPCRs: computational modeling of the dopamine $\mathrm{D} 2$ receptor interaction 
with the GIPC1 - PDZ-domain. Biochim Biophys Acta Biomembr 1848:976-983. https://doi.org/10.1016/j.bbamem.2014.12.002

Serrano-Vega MJ, Magnani F, Shibata Y, Tate CG (2008) Conformational thermostabilization of the beta1-adrenergic receptor in a detergent-resistant form. Proc Natl Acad Sci U S A 105:877882. https://doi.org/10.1073/pnas.0711253105

Shiraishi Y, Natsume M, Kofuku Y et al (2018) Phosphorylation-induced conformation of $\beta 2$-adrenoceptor related to arrestin recruitment revealed by NMR. Nat Commun 9:194. https://doi.org/10.1038/ s41467-017-02632-8

Sixl F, Watts A (1985) Deuterium and phosphorus nuclear magnetic resonance studies on the binding of polymyxin B to lipid bilayerwater interfaces. Proc Natl Acad Sci U S A 80:1613-1615

Sommer ME, Smith WC, Farrens DL (2006) Dynamics of arrestinrhodopsin interactions: acidic phospholipids enable binding of arrestin to purified rhodopsin in detergent. J Biol Chem 281:94079417. https://doi.org/10.1074/jbc.M510037200

Soubias O, Teague WE, Gawrisch K (2006) Evidence for specificity in lipid-rhodopsin interactions. J Biol Chem 281:33233-33241. https://doi.org/10.1074/jbc.M603059200

Soubias O, Teague WE, Hines KG et al (2010) Contribution of membrane elastic energy to rhodopsin function. Biophys J 99:817-824. https://doi.org/10.1016/j.bpj.2010.04.068

Sounier R, Mas C, Steyaert J et al (2015) Propagation of conformational changes during mu-opioid receptor activation. Nature 524:375-378. https://doi.org/10.1038/nature14680

Staus DP, Wingler LM, Pichugin D et al (2019) Detergent- and phospholipid-based reconstitution systems have differential effects on constitutive activity of G-protein-coupled receptors. J Biol Chem 294:13218-13223. https://doi.org/10.1074/jbc.AC119.009848

Staus DP, Hu H, Robertson MJ et al (2020) Structure of the M2 muscarinic receptor- $\beta$-arrestin complex in a lipid nanodisc. Nature 579: 297-302. https://doi.org/10.1038/s41586-020-1954-0

Simon MI, Strathmann MP, Gautam N (1991) Diversity of G proteins in signal transduction. Science 252:802-808. https://doi.org/10.1126/ science.1902986

Strohman MJ, Maeda S, Hilger D et al (2019) Local membrane charge regulates $\beta 2$ adrenergic receptor coupling to Gi3. Nat Commun 10: 2234. https://doi.org/10.1038/s41467-019-10108-0

Sun C, Benlekbir S, Venkatakrishnan P et al (2018) Structure of the alternative complex III in a supercomplex with cytochrome oxidase. Nature 557:123-126. https://doi.org/10.1038/s41586-018-0061-y

Tate CG, Schertler GF (2009) Engineering G protein-coupled receptors to facilitate their structure determination. Curr Opin Struct Biol 19: 386-395. https://doi.org/10.1016/j.sbi.2009.07.004

Teo ACK, Lee SC, Pollock NL et al (2019) Analysis of SMALP coextracted phospholipids shows distinct membrane environments for three classes of bacterial membrane protein. Sci Rep 9:1813. https://doi.org/10.1038/s41598-018-37962-0

Tsukamoto H, Sinha A, DeWitt M, Farrens DL (2010) Monomeric rhodopsin is the minimal functional unit required for arrestin binding. J Mol Biol 399:501-511. https://doi.org/10.1016/j.jmb.2010.04.029

Tsukamoto H, Szundi I, Lewis JW et al (2011) Rhodopsin in nanodiscs has native membrane-like photointermediates. Biochemistry 50: 5086-5091. https://doi.org/10.1021/bi200391a

Van Eps N, Caro LN, Morizumi T et al (2017) Conformational equilibria of light-activated rhodopsin in nanodiscs. Proc Natl Acad Sci U S A 114:E3268-E3275. https://doi.org/10.1073/pnas.1620405114

Van Eps N, Altenbach C, Caro LN et al (2018) Gi- and Gs-coupled GPCRs show different modes of G-protein binding. Proc Natl Acad Sci U S A 115:2383-2388. https://doi.org/10.1073/pnas. 1721896115
Vélez-Ruiz GA, Sunahara RK (2011) Reconstitution of G proteincoupled receptors into a model bilayer system: reconstituted highdensity lipoprotein particles. Methods Mol Bio 756:167-182

Vishnivetskiy SA, Ostermaier MK, Singhal A et al (2013) Constitutively active rhodopsin mutants causing night blindness are effectively phosphorylated by GRKs but differ in arrestin-1 binding. Cell Signal 25:2155-2162. https://doi.org/10.1016/j.cellsig.2013.07.009

Vögler O, Casas J, Capó D et al (2004) The G $\beta \gamma$ dimer drives the interaction of heterotrimeric $\mathrm{G}$ i proteins with nonlamellar membrane structures. J Biol Chem 279:36540-36545. https://doi.org/ 10.1074/jbc.M402061200

Wang J, Hua T, Liu ZJ (2020) Structural features of activated GPCR signaling complexes. Curr Opin Struct Biol 63:82-89. https://doi. org/10.1016/j.sbi.2020.04.008

Watts A (1993) Magnetic resonance studies of phospholipid-protein interactions in bilayers. In: Cevc G (ed) Phospholipids handbook. Marcel Dekker, New York, pp 687-740

Watts A, Volotovski ID, Marsh D (1979) Rhodopsin-lipid associations in bovine rod outer segment membranes. Identification of Immobilized Lipid by Spin-Labels. Biochemistry 18:5006-5013. https://doi.org/ 10.1021/bi00589a031

Weis WI, Kobilka BK (2018) The molecular basis of G protein-coupled receptor activation. Annu Rev Biochem 87:897-919. https://doi.org/ 10.1146/annurev-biochem-060614-033910

Whorton MR, Bokoch MP, Rasmussen SGF et al (2007) A monomeric G protein-coupled receptor isolated in a high-density lipoprotein particle efficiently activates its $\mathrm{G}$ protein. Proc Natl Acad Sci U S A 104:7682-7687. https://doi.org/10.1073/pnas.0611448104

Whorton MR, Jastrzebska B, Park PSH et al (2008) Efficient coupling of transducin to monomeric rhodopsin in a phospholipid bilayer. J Biol Chem 283:4387-4394. https://doi.org/10.1074/jbc.M703346200

Wingler LM, Elgeti M, Hilger D et al (2019) Angiotensin analogs with divergent bias stabilize distinct receptor conformations. Cell 176: 468-478.e11. https://doi.org/10.1016/j.cell.2018.12.005

Yasuhara K, Arakida J, Ravula T et al (2017) Spontaneous lipid nanodisc fomation by amphiphilic polymethacrylate copolymers. J Am Chem Soc 139:18657-18663. https://doi.org/10.1021/jacs.7b10591

Ye L, Van Eps N, Zimmer M et al (2016) Activation of the A2A adenosine G-protein-coupled receptor by conformational selection. Nature 533:265-268. https://doi.org/10.1038/nature17668

Ye L, Neale C, Sljoka A et al (2018) Mechanistic insights into allosteric regulation of the A2A adenosine $\mathrm{G}$ protein-coupled receptor by physiological cations. Nat Commun 9:1372. https://doi.org/10. 1038/s41467-018-03314-9

Yen H-Y, Hoi KK, Liko I et al (2018) PtdIns(4,5)P2 stabilizes active states of GPCRs and enhances selectivity of G-protein coupling. Nature 559:423-427. https://doi.org/10.1038/s41586-018-0325-6

Yin J, Chen KYM, Clark MJ et al (2020) Structure of a D2 dopamine receptor-G-protein complex in a lipid membrane. Nature 584:125129. https://doi.org/10.1038/s41586-020-2379-5

Yoshiura C, Kofuku Y, Ueda T et al (2010) NMR analyses of the interaction between CCR5 and its ligand using functional reconstitution of CCR5 in lipid bilayers. J Am Chem Soc 132:6768-6777. https:// doi.org/10.1021/ja100830f

Zhao DY, Pöge M, Morizumi T et al (2019) Cryo-EM structure of the native rhodopsin dimer in nanodiscs. J Biol Chem 294:1421514230. https://doi.org/10.1074/jbc.RA119.010089

Publisher's note Springer Nature remains neutral with regard to jurisdictional claims in published maps and institutional affiliations. 